\title{
32. SEQUENCE AND LONGEVITY OF BASALT ALTERATION AT DEEP SEA DRILLING PROJECT SITE 5971
}

\author{
Curt Peterson, Robert Duncan, and Kenneth F. Scheidegger, College of Oceanography, Oregon State University ${ }^{2}$
}

\begin{abstract}
Preliminary studies of hydrothermally altered massive basalts formed at the fast-spreading Mendoza Rise and recovered from DSDP Holes 597B and 597C indicate the presence of three secondary mineral assemblages which formed in the following order: (1) trioctahedral chlorite and talc, (2) goethite and smectite, and (3) calcite and celadonite. The sequential precipitation of these mineral assemblages denotes high water:rock ratios and time-varying conditions of temperature (early $>200^{\circ} \mathrm{C}$ to late $<30^{\circ} \mathrm{C}$ ) and state of oxidation (early nonoxidative to late oxidative). A decrease in the relative proportion of oxidative mineral assemblages with depth to $70 \mathrm{~m}$ in Site 597 basement indicates a zone of oxidative alteration that became shallower with time as the deeper, more constricted fracture systems were filled by secondary mineralization.

In this report we present the first results of the $\mathrm{K}-\mathrm{Ar}$ dating of celadonite formation age; celadonite formation reflects end-stage hydrothermal alteration in Site 597 basement. Three celadonite dates obtained from Site 597 samples include $13.1 \pm 0.3 \mathrm{~m} . \mathrm{y}$. from $17 \mathrm{~m}$ basement depth (Hole 597B), $19.9 \pm 0.4 \mathrm{~m} . \mathrm{y}$. from $18 \mathrm{~m}$ basement depth (Hole $597 \mathrm{C}$ ), and $19.3 \pm 1.6 \mathrm{~m} . \mathrm{y}$. from $60 \mathrm{~m}$ basement depth (Hole 597C).

The age of host rock crystallization ( $28.6 \mathrm{~m} . \mathrm{y}$.) and the $\mathrm{K}-\mathrm{Ar}$ dates of celadonite formation establish that hydrothermal alteration in the upper $70 \mathrm{~m}$ of Site 597 basement continued for at least $10 \mathrm{~m} . \mathrm{y}$. and possibly as long as $16 \mathrm{~m} . \mathrm{y}$. after basalt crystallization at the ridge crest. Assuming a half-spreading rate of $55 \mathrm{~km} / \mathrm{m}$.y., we calculate that hydrothermal circulation was active in shallow basement at a distance of at least $550 \mathrm{~km}$ off ridge crest and possibly as far as $1000 \mathrm{~km}$ off ridge crest.
\end{abstract}

\section{INTRODUCTION}

\section{Factors that Affect Hydrothermal Alteration}

The thermally driven circulation of marine water through oceanic basalts formed at spreading ridge axes is known to be an important process in controlling the mobilization and exchange of chemical elements between seawater and the oceanic crust (Hart, 1970; Thompson, 1983). However, the degree of such interaction and the hydrothermal alteration associated with it is different at different crustal sites. The degree of interaction probably depends on basalt permeability, the temperature and composition of the circulating fluids (Stakes and O'Neil, 1982), and the duration of hydrothermal circulation (Honnorez, 1983). Experimental studies have helped to establish the relative importance of some of these factors in controlling seawater-basalt interaction (Mottl and Seyfried, 1980; Rosenbauer and Bischoff, 1983). Still more needs to be known about the duration of alteration and the range of hydrothermal conditions at crustal sites that differ greatly in, for example, permeability, spreading ridge rate of formation, and sediment cover. Such knowledge is needed to constrain models of large-scale seawater-crust interactions.

\section{Scope of this Study}

In this chapter we examine the nature, sequence, and timing of the secondary mineralization associated with

\footnotetext{
${ }^{1}$ Leinen, M., Rea, D. K., et al., Init. Repts. DSDP, 92: Washington (U.S. Govt. Printing Office).

2 Address: College of Oceanography, Oregon State University, Corvallis, OR 97331.
}

the hydrothermal alteration of the massive ocean floor basalts at Site 597 . The basalts formed at a very-fastspreading ridge and are covered by a relatively thin blanket of unconsolidated sediments. Our study includes a brief description of the modes of occurrence of the secondary minerals that appear downcore in the Site 597 basalt fractures and vesicles. This description is based on the microscopic examination of rock faces and on petrographic analyses of thin sections. This part of the study is followed by a more detailed summary of the results of (1) X-ray diffraction analyses of alteration product mineralogy, (2) microprobe analyses of secondary mineral composition, and (3) estimates of the duration of hydrothermal alteration based on the $\mathrm{K}-\mathrm{Ar}$ dating of celadonite. Finally, we compare these results with published reports of seafloor basalt alteration and present a general model for the hydrothermal alteration of massive basalts formed at fast-spreading ridges.

\section{Site 597 Characteristics}

Site 597 is located in 28.6-m.y.-old crust some 150 $\mathrm{km}$ northwest of the Austral Fracture Zone. The crust formed at the fossil Mendoza Rise, which has a halfspreading rate of $55.4 \mathrm{~km} / \mathrm{m}$.y. (Rea, this volume). At a seafloor depth of $4150 \mathrm{~m}$, two holes (597B and 597C) were drilled through $\approx 55 \mathrm{~m}$ of overlying unconsolidated sediment; they penetrated igneous basement to a depth of 24.6 and $91 \mathrm{~m}$, respectively. The recovered basalt is fine to medium grained, massive, and may consist of two or more flow units; there is no evidence of intervening breccia, pillows, or zones of flow top alteration (Site 597 chapter, this volume). Vesicularity and fracture spacing are moderate in the upper $20 \mathrm{~m}$ of Site 597 ba- 
salt but decrease significantly with increasing depth in Hole 597C. The predominant mineral phases in unaltered basalt include, in order of average abundance, plagioclase, clinopyroxene, magnetite, glass, and olivine.

\section{METHODS}

Secondary minerals were microscopically examined for their mode of occurrence (i.e., as fracture fillings, veins, and amygdules, and in pervasive whole rock alteration) in basalt fragments from Holes 597B (2 samples) and 597C (24 samples). Secondary minerals were subsequently scraped from fracture fillings and from amygdules of sufficient size to exclude the possibility that they resulted from contamination by primary mineral phases in host rocks. Alteration product separates were then prepared for X-ray diffraction analysis, and thin sections of host rock were polished for microprobe analysis.

The mineral data presented in this report were obtained by the $\mathrm{X}$-ray diffraction methods described by Scheidegger and Stakes (1980). Randomly mounted, untreated separates were scanned with Ni-filtered, monochromatic $\mathrm{CuK} \alpha$ radiation from 3 to $30^{\circ} 2 \theta$ at $0.3^{\circ} 2 \theta / \mathrm{min}$. and from 59 to $63^{\circ} 2 \theta$ at $0.1^{\circ} 2 \theta / \mathrm{min}$. to study 060 reflections. Oriented mounted separates were magnesium saturated, ethylene glycolated, and scanned from 3 to $30^{\circ} 2 \theta$ at $0.3^{\circ} 2 \theta / \mathrm{min}$. to document expandable 001 basal reflections. Chemical data on selected secondary mineral phases were obtained by the microprobe analysis of the fracture-filling and vein material remaining in the basalt fragments after initial scraping. Microprobe analysis of pore-space material was also performed on amygdules too small to be sampled for X-ray diffraction analysis. Chlorite, goethite, and calcite were used as standards, and sample beam totals are consistent with corresponding standard beam totals.

Celadonite or celadonitic clay was identified by X-ray diffraction in five samples from altered basalts at Site 597. Sufficient material for age determinations ( $\geq 0.1 \mathrm{~g}$ ) could be obtained from fracture fillings in only three of these samples, however. Ages were determined on the separated minerals by using conventional K-Ar techniques (Dalrymple and Lanphere, 1978). Potassium concentrations were measured by atomic absorption spectrophotometry. Argon isotopic compositions were determined by using an AEI MS-10S mass spectrometer with on-line, high-vacuum extraction lines and a ${ }^{38} \mathrm{Ar}$ spike pipette system. The extraction lines were baked for $18 \mathrm{hr}$. at low temperature $\left(100^{\circ} \mathrm{C}\right)$ while connected to oil diffusion pumps to remove atmospheric gases and create low pressures prior to sample fusion. Active gases released during fusion were gettered on hot $\mathrm{Ti}-\mathrm{TiO}_{2}$ sponge metal before $\mathrm{Ar}$ measurement.

All sample depths refer to depths in basement. Sub-bottom basement depths of $48 \mathrm{~m}$ and $52.50 \mathrm{~m}$ were assumed for Holes 597B and 597C, respectively.

\section{PETROGRAPHIC ANALYSES AND MODES OF SECONDARY MINERAL OCCURRENCE}

The alteration of 26 Site 597 basalt samples (Table 1) ranged from the pervasive alteration of unstable grains and groundmass (in some samples alteration products make up $>30 \%$ of rock volume) to texturally fresh basalts with secondary mineralization mostly confined to fracture fillings (in these samples alteration products make up $<5 \%$ of rock volume). The groundmass in the pervasively altered samples from the upper $17 \mathrm{~m}$ of Holes $597 \mathrm{~B}$ and $597 \mathrm{C}$ is largely replaced by carbonate and zeolite and lesser amounts of brown birefringent clays and iron-stained black opaques. Altered clinopyroxene grains are typically replaced by birefringent clays or opaques and show considerable iron-oxide staining.

Fracture fillings and amygdules in the pervasively altered basalts contain variable combinations of alteration products, including yellow, brown, and green birefringent clays; black opaques; carbonate; and blue green mica. Amygdules are often concentrically layered, the layering suggesting sequential secondary mineralization. The linings and outer layers of such amygdules comprise yellow or green birefringent clays, and the inner layers and centers contain one or more of the following: dark green clay, black opaques, carbonate, and blue green micas. Concentrically banded amygdule inner layers in Samples 597C-3-1a and 597C-3-1b (Plates 1 and 2) show black opaques forming after yellow and light green clays and blue green micas and carbonates forming after the opaques. When both are present, dark green clay consistently precedes blue green mica. Evidence of successive alteration or late overprinting of secondary minerals is suggested by the iron staining of amygdule rims and carbonate centers.

The sequence of secondary mineralization in the fracture fillings of the pervasively altered basalts is less clear. Extensive iron-oxide staining and the partial replacement of dark olive green, tabular crystals by green birefringent clays and opaques in fracture linings mask initial crystallization sequences. However, the sequence of secondary mineralization is well preserved in fractures from Samples 597B-3-1b and 597C-3-1b and proceeds from dark olive green, tabular crystals and green birefringent clays in linings to dark green clays, black opaques, carbonate, and blue green mica in fracture centers (Table 1). Carbonate and blue green mica crystals are clearly intergrown in several of the fracture filling centers of Sample 597B-3-1b.

Incipient fractures or veins in the pervasively altered basalt samples are defined by the replacement of groundmass by diffuse haloes, $>1 \mathrm{~mm}$ in diameter, of ironstained carbonate and zeolite. These veins were apparently important as conduits of fluids during the pervasive alteration of the uppermost basement basalts.

In basalt samples below basement depths of $17 \mathrm{~m}$ in Hole 597C, the alteration of unstable grains and groundmass tends to decrease with increasing depth. In altered basalts below basement depths of $30 \mathrm{~m}$, fracture fillings are the predominant sites of secondary mineralization. The sequence of the infilling of fractures in altered basalts (e.g., Samples 597C-7-3 and 597C-9-3a; Table 1) records several secondary mineralization events. The absence of textural evidence for alteration away from these fracture boundaries suggests that hydrothermal circulation during the successive mineralization events might have been short lived or episodic. The fracture linings are made up of at least one of the following: (1) pale yellow brown, foliated crystals, (2) dark olive green, tabular crystals, (3) green birefringent clay, and (4) black opaques. Fracture centers typically contain carbonate and/or blue green mica (Table 1). However, fracture fillings from basalt Samples 597C-10-1 and 597C-10-6, at $>66 \mathrm{~m}$ basement depth, are completely filled with (1) yellow brown foliated crystals, (2) dark olive green, tabular crystals, and (3) minor amounts of unstained black opaques. There was no petrographic evidence of the alteration of the secondary minerals themselves (e.g., mineral replacement or iron staining in fracture linings) in samples from $>60 \mathrm{~m}$ basement depth in Hole 597C. 
Table 1. Observed modes of secondary mineral occurrence and sampling intervals from altered basalts, Holes 597B, 597C.

\begin{tabular}{|c|c|c|c|c|c|c|c|c|c|c|c|c|c|}
\hline Core-Section & Sample & $\begin{array}{l}\text { Sub-basement } \\
\text { depth } \\
\text { (m) }\end{array}$ & 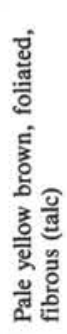 & 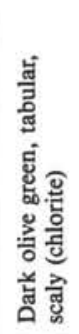 & 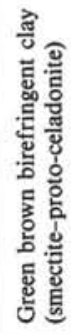 & 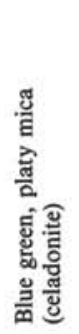 & 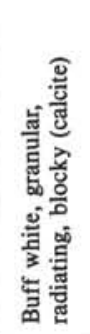 & 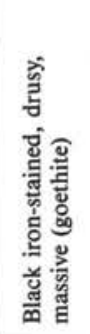 & 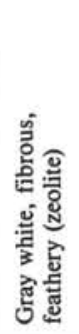 & 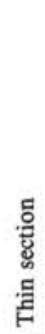 & 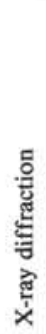 & 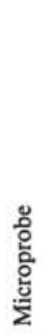 & 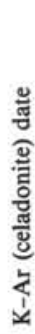 \\
\hline \multicolumn{14}{|l|}{ Hole 597B } \\
\hline $\begin{array}{l}3-1 \\
3-1\end{array}$ & $\begin{array}{l}a \\
b\end{array}$ & $\begin{array}{l}15.90 \\
16.75\end{array}$ & & $\mathrm{Fl}, \mathrm{V}$ & $\begin{array}{l}\text { A, P } \\
\text { Fc, A }\end{array}$ & Fc & $\begin{array}{c}\text { F, P } \\
\text { Fc, Ac }\end{array}$ & $\begin{array}{c}F \\
F c, V\end{array}$ & $\begin{array}{l}\mathrm{P} \\
\mathrm{P}\end{array}$ & $r$ & $r$ & & $r$ \\
\hline \multicolumn{14}{|l|}{ Hole 597C } \\
\hline $3-1$ & a & 3.34 & & & $\mathrm{Fl}, \mathrm{Al}$ & Ac & $\mathrm{P}, \mathrm{Ac}$ & Ac & P & $r$ & $r$ & $r$ & \\
\hline $3-1$ & b & 3.92 & & Fl & $\mathrm{Fl}, \mathrm{Al}$ & Ac & $\mathrm{Fc}, \mathrm{Ac}$ & $\mathrm{Fc}, \mathrm{Ac}$ & P & $r$ & $r$ & $r$ & \\
\hline $3-2$ & & 5.35 & & & $\mathrm{Fl}$ & & $\mathrm{Fc}$ & Fl & P & $r$ & $r$ & $r$ & \\
\hline $4-1$ & a & 12.16 & & Fl & $\mathrm{F}, \mathrm{A}$ & Fc & P & $\mathrm{F}, \mathrm{V}$ & P & $r$ & $r$ & & \\
\hline $4-1$ & b & 12.86 & F1 & Fl & FI & & $\mathrm{Fc}$ & F & & $r$ & & $r$ & \\
\hline $4-4$ & a & 16.56 & & & & & & F & & $r$ & & & \\
\hline $4-4$ & b & 17.24 & & F & $\mathrm{F}, \mathrm{Al}$ & $\mathrm{F}, \mathrm{Ac}$ & F, Ac & F & v & & $r$ & & \\
\hline $4-5$ & & 17.77 & & Fl & F1 & $\mathrm{Fc}$ & & F & & & $r$ & $r$ & $r$ \\
\hline $6-1$ & & 30.55 & & & & & $A, V$ & Fl & v & $r$ & $r$ & & \\
\hline $6-3$ & & 33.55 & F & F & & & & F & & $r$ & & & \\
\hline $6-4$ & & 34.92 & & F1 & F & & $\mathrm{Fc}$ & F & & & & & \\
\hline $6-5$ & & 36.56 & & F1 & Fl & & Fc & F & & $r$ & $r$ & & \\
\hline $7-3$ & & 42.61 & & $\mathrm{Fl}$ & & & $\mathrm{Fc}$ & Fl & & $r$ & $r$ & & \\
\hline $7-4$ & & 44.34 & Fl & $\mathrm{Fc}$ & & & & $\mathrm{Fc}$ & & & $r$ & & \\
\hline $8-2$ & & 50.72 & & & & & & & & & $r$ & & \\
\hline $8-4$ & a & 52.62 & F & F & & & & & & & & & \\
\hline $8-4$ & b & 53.29 & F & F & & & & v & & $r$ & & & \\
\hline $9-1$ & & 57.60 & Fl & F1 & F & $\mathrm{Fc}$ & Fc & $\mathrm{Fl}$ & & $r$ & $r$ & & \\
\hline $9-3$ & a & 60.33 & & Fl & Fl & $\mathrm{Fc}$ & $\mathrm{Fc}$ & $\mathrm{F} 1$ & & & & & \\
\hline $9-3$ & b & 60.35 & & $\mathrm{Fl}$ & & $\mathrm{Fc}$ & & $\mathrm{Fl}$ & & & $r$ & & $r$ \\
\hline $10-1$ & & 66.05 & $\mathrm{~F}$ & $\mathrm{~F}$ & F & & & F & & $r$ & $r$ & & \\
\hline $10-3$ & a & 69.90 & F & F & & & & & & & & & \\
\hline $10-3$ & b & 69.92 & F & F & & & & & & & & & \\
\hline $10-6$ & & 74.35 & F & $\mathrm{F}$ & & & & $\mathrm{Fc}$ & & $r$ & $r$ & $r$ & \\
\hline
\end{tabular}

Note: $\mathrm{F}=$ fracture filling; $\mathrm{Fl}=$ fracture lining; $\mathrm{Fc}=$ fracture center $\mathrm{A}=$ amygdule filling; $\mathrm{Al}=$ amygdule lining; $\mathrm{Ac}=$ amygdule center; $\mathrm{V}=$ vein, incipient fracture, or zone of alteration; $\mathrm{P}=$ pervasive alteration of unstable grains and groundmass.

\section{X-RAY DIFFRACTION ANALYSES AND MINERALOGY OF SECONDARY MINERALS}

Fracture and amygdule mineral separates from 17 basalt samples were analyzed by X-ray diffraction, and representative diffractograms of the mineral separates from randomly mounted, untreated slides are shown in Figure 1. The mineral phases identified include a smectite 001 peak at $\approx 14.5$ to $15.0 \AA$ ( 6.1 to $5.9^{\circ} 2 \theta$ expanding), a chlorite 001 peak at $\approx 14.0 \AA\left(6.2^{\circ} 2 \theta\right.$ non-expanding $)$, a celadonite 001 peak at $\approx 9.8 \AA\left(9.2^{\circ} 2 \theta\right)$, a talc 002 peak at $9.2 \AA(9.62 \theta)$, a phillipsite 020 peak at $\approx 7.1 \AA$ $\left(12.4^{\circ} 2 \theta\right)$, a goethite 002 peak at $5.0 \AA\left(17.7^{\circ} 2 \theta\right)$, an aragonite 111 peak at $3.4 \AA\left(25.8^{\circ} 2 \theta\right.$; not shown in Fig. 1), and a calcite 104 peak at $3.0 \AA\left(29.7^{\circ} 2 \theta\right)$. In addition, weak peaks at $23 \AA$ (Samples $597 \mathrm{C}-4-5$ and 597C-10-6) and at $25 \AA$ (Sample 597B-3-1b) suggest the presence of mixed-layer chlorite-talc and smectite-mica minerals, respectively (Fig. 1). Mg saturation and glycolation did not affect the $23-\AA$ peaks but did diminish the $25-\AA ̊$ and $15-\AA ̊$ peaks associated with smectite basal spacings. The broad nature of the smectite 001 peaks (Fig. 1) and the irregular expansion of the basal spacings im- plies a poorly crystalline or irregularly ordered structure for the smectites analyzed. The smectite 001 peaks in Samples 597B-3-1b and 597C-4-5 were found to collapse to $9^{\circ} 2 \theta$ upon heating to $300^{\circ} \mathrm{C}$ for $1 \mathrm{hr}$., but the chlorite 001 peaks at $14 \AA$ were unaffected.

Broad, ill-defined peaks also occur between $8^{\circ}$ and $9^{\circ} 2 \theta$ in mineral separates from Samples 597B-3-1b and 597C-4-5 (Fig. 1). We attribute these peaks to poorly ordered celadonitic clay 001 spacings. Such weakly crystalline celadonite, or proto-celadonite, might be deficient in $\mathrm{K}$ and possibly interlayered with smectite (Scheidegger and Stakes, 1980). A much-better-defined 001 celadonite peak is found in Sample 597C-9-3b (Fig. 1). A strong 060 spacing of $1.510 \AA$ undoubtedly corresponds to the Fe-rich dioctahedral celadonite in Sample 597C-9$3 \mathrm{~b}$.

Although 060 reflections ranging from $1.506 \AA$ to $1.516 \AA$ denote dioctahedral phyllosilicates in Samples 597B-3-1b, 597C-4-5, and 597C-9-3b, only trioctahedral chlorite and talc were found in Sample 597C-10-6, which shows a dominant 060 spacing of $1.529 \AA$ (Fig. 2). It is significant that dominant 060 spacings tend to increase with increasing sample depth (from $1.510 \AA$ to $1.53 \AA$; 


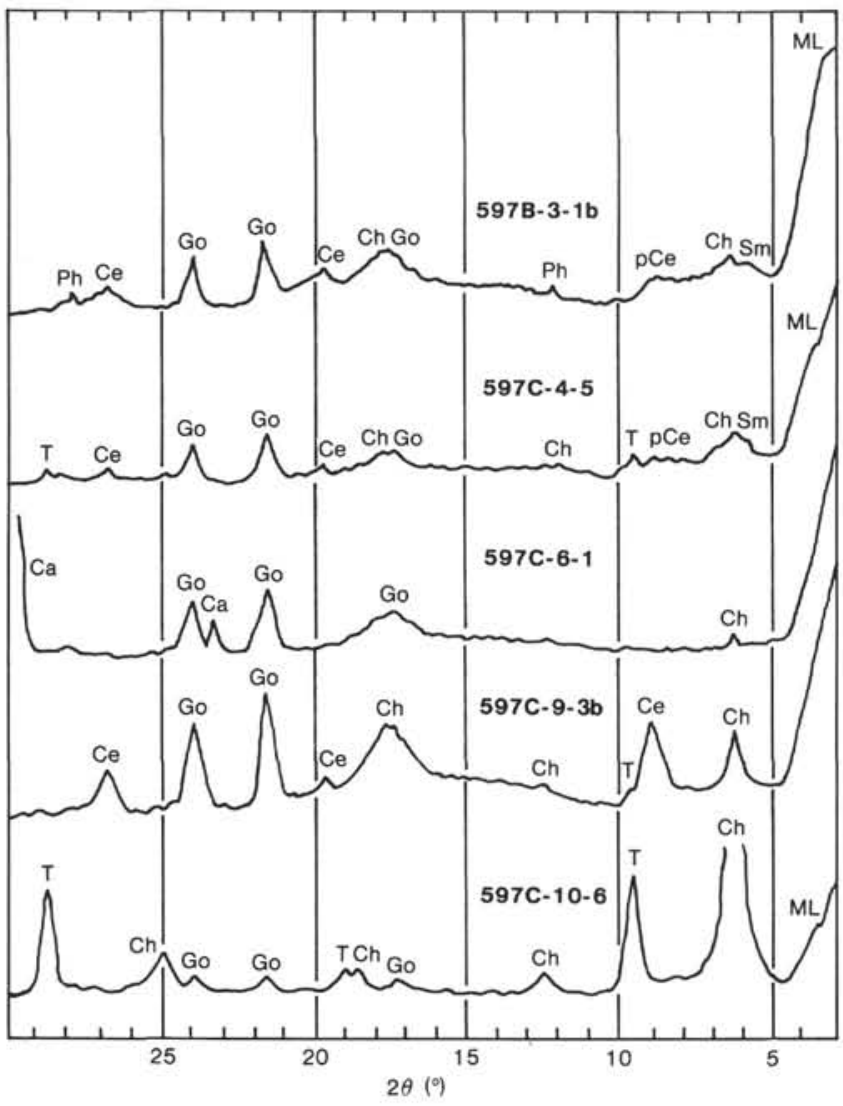

Figure 1. Diffractograms of representative secondary mineral separates, randomly mounted and untreated. $\mathrm{ML}=$ mixed-layer phyllosilicates; $\mathrm{Sm}=$ smectite $; \mathrm{Ch}=$ chlorite $; \mathrm{pCe}=$ celadonitic clay (proto-celadonite); $\mathrm{Ce}=$ celadonite; $\mathrm{T}=$ talc; $\mathrm{Ph}=$ phillipsite; $\mathrm{Go}=$ goethite; $\mathrm{Ca}=$ calcite.

Fig. 3). This trend demonstrates a shift from dioctahedral (Fe-rich) phyllosilicates at shallow $(<20 \mathrm{~m})$ basement depths to trioctahedral (Mg-rich) phyllosilicates at deeper $(>60 \mathrm{~m})$ basement depths. It is likely that trioctahedral phyllosilicates were initially precipitated throughout the upper $70 \mathrm{~m}$ of basement, but that the subsequent precipitation of dioctahedral phyllosilicates under more oxidative conditions continued at successively shallower depths as time progressed.

The two major nonsilicate phases in the 17 mineral separates analyzed are calcite and goethite. A well-defined peak at $3.70 \AA\left(24.1^{\circ} 2 \theta\right)$ is intimately associated with the goethite 002 and 011 peaks, respectively, at 4.97 $\AA$ and $4.18 \AA$ (Fig. 2). A strong reflection at $3.70 \AA$ however, is not predicted for goethite (ASTM Card File Index $3-249$ ), and the $3.70-\AA$ peak is presently unaccounted for.

The presence or absence in the thin sections of the mineral phases identified in the diffractograms of the same samples allows us to match the optical and mineralogical properties of the major secondary mineral phases. For example, pale yellow brown, foliated crystals and dark olive green, tabular crystals correspond to talc and chlorite, respectively. Similarly, yellow green birefringent clays and blue green platy mica correspond to smectite and celadonite, respectively. The dark green "clay" that

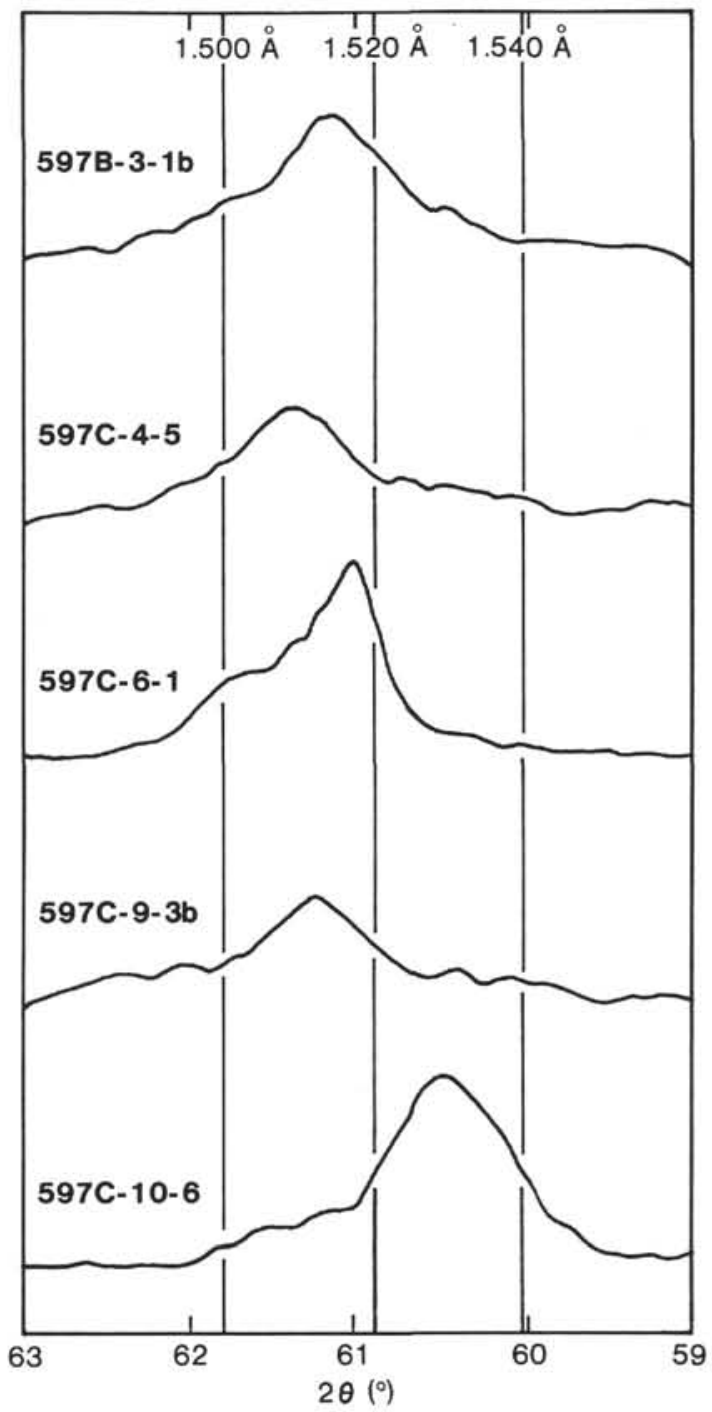

Figure 2. Diffractograms of representative phyllosilicate 060 spacings. Trioctahedral phyllosilicates have 060 spacings closer to $1.530 \AA$, and dioctahedral forms have spacings closer to $1.510 \AA$.

fills fracture and amygdule centers represents an intermediate clay-mica phase (celadonitic clay). Carbonate typically occurs as calcite, and iron-stained opaques include goethite. At least one zeolite has been identified as phillipsite; however, the presence of only trace amounts of zeolites in analyzed separates precludes further identification of zeolite phases.

\section{RELATIVE ABUNDANCE OF SECONDARY MINERALS}

Primary peak heights for the secondary minerals analyzed were measured and summed for each of 16 sample diffractograms. Relative mineral abundances were computed for each sample on the basis of primary peak height as a percentage of total measured peak heights (Table 2). Internal standards were not included in the $\mathrm{X}$-ray diffraction analyses, and so relative abundances apply only to individual samples. As shown in Table 2, calcite, goethite, and chlorite are the most abundant mineral phases formed in the Site 597 basalt fracture fill- 


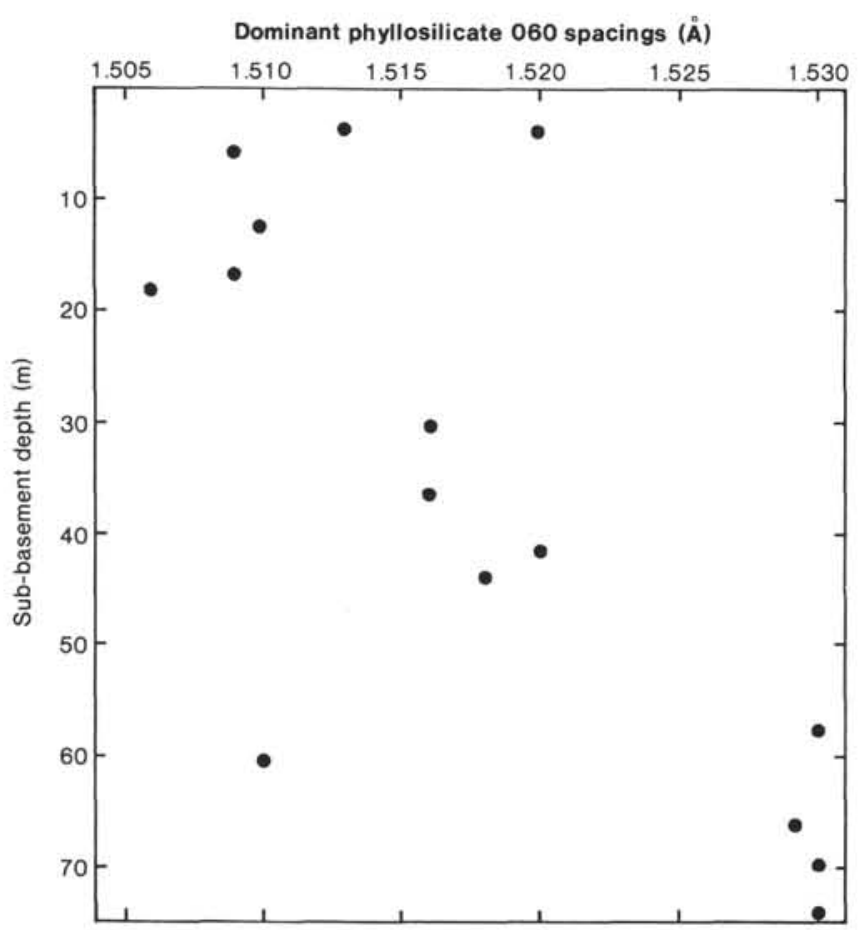

Figure 3. A plot of dominant 060 phyllosilicate spacings versus depth in basalt from Hole 597C. The increase in 060 spacing with depth in basalt indicates a transition from dioctahedral phyllosilicates at shallower basement depths to trioctahedral forms at deeper basement levels.

ings. Talc, smectite, and celadonite are generally less abundant than chlorite, goethite, and calcite. Phillipsite and aragonite occur only rarely.

It is interesting that the relative abundance of several mineral phases changes downcore. For example, both chlorite and talc increase in relative abundance below basement depths of $17 \mathrm{~m}$, whereas calcite increases in relative abundance above basement depths of $44 \mathrm{~m}$. By comparison, neither goethite nor smectite shows consis- tent downcore changes in relative abundance in the basement interval studied. The remaining phases identified (celadonite, phillipsite, and aragonite) occur too infrequently in the mineral separates analyzed to establish patterns of downcore variation.

From the downcore presence, absence, and relative abundance of the mineral phases presented above, it is possible to group five of the mineral phases into these assemblages. Chlorite and talc form one assemblage (prevalent below $17 \mathrm{~m}$ basement depth), and goethite and smectite form a second assemblage (common throughout the basalt section studied). Calcite forms the third assemblage; it is generally abundant in samples from basement depths of 0 to $44 \mathrm{~m}$. The extensive overlapping of these three assemblages is consistent with the sequential formation of the mineral associations observed in sample thin sections. However, the different downcore distributions of these assemblages confirms the previously established downcore variability of the nature and duration of basalt alteration at Site 597 .

\section{MICROPROBE ANALYSES AND ELEMENTAL COMPOSITIONS OF SECONDARY MINERALS}

Microprobe analysis, using a defocused beam, was performed on a variety of amygdule and fracture fillings that showed petrographic evidence of sequential secondary mineralization. Elemental analyses of four amygdules and three fracture fillings that are representative of the sequential secondary mineralization at Site 597 are presented in Table 3. An amygdule in Sample 597C$3-1 \mathrm{a}$ at $3.34 \mathrm{~m}$ depth in basement is filled with a yellow green birefringent clay that becomes darker green toward the amygdule center. Microprobe analysis of the clay filling (Table 3) indicates a $\mathrm{Mg}$ - and Fe-rich smectite $(16.23 \%$ $\mathrm{Mg}, 23.34 \% \mathrm{FeO}$, and $39.33 \% \mathrm{SiO}_{2}$ ) amygdule lining. A structural formula for this smectite, calculated on the basis of 22 oxygens (Humphris et al., 1980), is of the form

Table 2. Relative abundances of secondary minerals forming amygdule and fracture fillings in altered basalts, Holes 597B, 597C.

\begin{tabular}{|c|c|c|c|c|c|c|c|c|c|c|c|c|c|}
\hline Core-Section & Sample & $\begin{array}{l}\text { Sub-basement } \\
\text { depth } \\
\text { (m) }\end{array}$ & $\begin{array}{l}\text { Mode of } \\
\text { occurrence }\end{array}$ & $\begin{array}{c}\text { Mixed-layer } \\
\text { (smectite-mica), } \\
25 \AA\end{array}$ & $\begin{array}{c}\text { Mixed-layer } \\
\text { (chlorite-talc), } \\
25 \AA\end{array}$ & $\begin{array}{c}\text { Smectite, } \\
15 \AA\end{array}$ & $\begin{array}{l}\text { Chlorite, } \\
14.0 \AA\end{array}$ & $\begin{array}{c}\text { Celadonite, } \\
9.8 \AA\end{array}$ & $\begin{array}{l}\text { Talc, } \\
9.2 \mathrm{~A}\end{array}$ & $\begin{array}{c}\text { Phillipsite, } \\
7.1 \AA \AA\end{array}$ & $\begin{array}{c}\text { Goethite, } \\
3.4 \mathrm{~A}\end{array}$ & $\begin{array}{c}\text { Aragonite, } \\
3.4 \mathrm{~A}\end{array}$ & $\begin{array}{l}\text { Calcite, } \\
3.0 \AA\end{array}$ \\
\hline \multicolumn{14}{|l|}{ Hole 597B } \\
\hline $3-1$ & a & 15.90 & A & & & $\mathrm{m}$ & $\mathrm{m}$ & & $\mathrm{m}$ & & $\mathrm{m}$ & & D \\
\hline $3-1$ & b & 16.75 & $\mathbf{F}$ & $\mathrm{X}$ & & $\mathrm{m}$ & M & M & & $\mathrm{m}$ & M & & $\mathrm{m}$ \\
\hline \multicolumn{14}{|l|}{ Hole $597 \mathrm{C}$} \\
\hline $3-1$ & a & 3.34 & F & & & & & & & & $\mathrm{m}$ & & D \\
\hline $3-1$ & b & 3.92 & A & & & & & & & m & M & $\mathrm{m}$ & $\mathrm{m}$ \\
\hline $3-2$ & & 5.35 & F & $\mathrm{x}$ & & $\mathrm{m}$ & M & & m & & M & & $\mathrm{m}$ \\
\hline $4-1$ & a & 12.6 & F & & & & $\mathrm{m}$ & & & & M & & M \\
\hline 4.4 & b & 17.24 & F & & & $\mathrm{m}$ & $\mathrm{m}$ & $\mathrm{m}$ & $\mathrm{m}$ & & D & $\mathrm{m}$ & m \\
\hline $4-5$ & & 17.77 & F & & $\mathrm{x}$ & $\mathrm{m}$ & $\mathrm{M}$ & $\mathrm{m}$ & $\mathrm{m}$ & & M & & \\
\hline $6-1$ & & 30.55 & F & & & & $\mathrm{m}$ & & & & $\mathrm{m}$ & & D \\
\hline 6-5 & & 36.56 & $\mathrm{~F}$ & & & $\mathrm{~m}$ & & & $\mathrm{~m}$ & & $\mathrm{~m}$ & & D \\
\hline $7-3$ & & 42.61 & F & & & $\mathrm{m}$ & $\mathrm{m}$ & & & & M & & M \\
\hline $7-4$ & & 44.34 & $\mathbf{F}$ & & & $\mathrm{m}$ & $\mathrm{m}$ & & $\mathrm{m}$ & & M & & \\
\hline $9-1$ & & 57.60 & F & & $x$ & $\mathrm{~m}$ & D & & $\mathrm{m}$ & & & & \\
\hline $9-3$ & b & 60.35 & F & & & & M & $\mathbf{M}$ & & & M & & $\mathrm{m}$ \\
\hline $10-1$ & & 66.05 & $\mathbf{F}$ & & & m & M & $\mathrm{m}$ & & & M & & \\
\hline $10-6$ & & 74.35 & F & & $x$ & & M & & M & & $\mathrm{m}$ & & \\
\hline
\end{tabular}

Note: $\mathrm{F}=$ fracture filling; $\mathrm{A}=$ amygdule filling; $\mathrm{X}=$ present: relative abundance not established; $\mathrm{D}=$ dominant: peak height is $>80 \%$ of total measured peaks; $\mathrm{M}=$ major: peak height is $20-80 \%$ of total measured peaks; $m=$ minor: peak height is $1-20 \%$ of total measured peaks. Quantities in $\AA$ are measured peak $D$-spacings. 
Table 3. Defocused microprobe analyses (wt.\%) of secondary minerals in amygdules and fracture fillings from altered basalts, Hole 597C.

\begin{tabular}{|c|c|c|c|c|c|c|c|c|c|c|c|c|c|}
\hline Core-Section & Sample & $\begin{array}{l}\text { Sub-basement } \\
\text { depth } \\
\text { (m) }\end{array}$ & $\begin{array}{l}\text { Mode of } \\
\text { occurrence }\end{array}$ & $\mathrm{SiO}_{2}$ & $\mathrm{Al}_{2} \mathrm{O}_{3}$ & $\mathrm{TiO}_{2}$ & $\mathrm{FeO}$ & $\mathrm{MnO}$ & $\mathrm{MgO}$ & $\mathrm{CaO}$ & $\mathrm{Na}_{2} \mathrm{O}$ & $\mathrm{K}_{2} \mathrm{O}$ & Total beam \\
\hline 3-1 & a & 3.34 & Al & 39.33 & 02.73 & 0.04 & 23.34 & 0.09 & 16.23 & 0.75 & 0.12 & 0.65 & 83.28 \\
\hline $3-1$ & a & & Ail & 48.34 & 3.16 & 0.03 & 20.49 & 0.09 & 0.18 & 0.54 & 0.01 & 5.50 & 78.34 \\
\hline $3-1$ & a & & Ac & 53.07 & 0.82 & nd & 21.2 & 0.06 & 6.58 & 0.51 & 0.03 & 5.82 & 88.13 \\
\hline $3-1$ & b & 3.92 & Al & 42.48 & 1.83 & nd & 20.05 & 0.08 & 17.40 & 0.65 & 0.09 & 0.53 & 83.17 \\
\hline $3-1$ & b & & Ail & 42.16 & 1.50 & nd & 24.08 & 0.10 & 16.21 & 0.56 & 0.12 & 0.64 & 85.41 \\
\hline $3-1$ & b & & Ac & 52.97 & 1.27 & nd & 20.91 & nd & 6.89 & 0.52 & 0.07 & 6.82 & 89.53 \\
\hline 3-1 & b & 3.92 & $\mathrm{Al}$ & 10.25 & 6.58 & 0.10 & 61.58 & 0.16 & 1.80 & 0.50 & 0.11 & 0.23 & 81.31 \\
\hline $3-1$ & b & & Ail & 4.18 & 7.99 & nd & 15.37 & 28.36 & 6.12 & 1.40 & 0.31 & 0.18 & $63.93^{\mathrm{a}}$ \\
\hline $3-1$ & b & & Ac & 0.11 & 0.82 & 0.06 & 1.39 & 66.36 & nd & 3.17 & 1.52 & 1.59 & $75.06^{\mathrm{a}}$ \\
\hline $3-2$ & & 5.35 & $\mathrm{Al}$ & 47.80 & 4.33 & 0.09 & 10.98 & 0.07 & 17.01 & 0.69 & 0.13 & 1.06 & 82.17 \\
\hline $3-2$ & & & Ac & nd & 0.23 & nd & 0.08 & nd & 1.44 & 58.64 & nd & 0.06 & $60.61^{\mathrm{a}}$ \\
\hline $3-2$ & & 5.35 & Al & 47.09 & 4.95 & 0.16 & 13.89 & 0.07 & 14.72 & 0.68 & 0.11 & 2.46 & 84.14 \\
\hline $3-2$ & & & Ac & nd & 0.15 & nd & nd & 0.06 & 1.40 & 59.70 & nd & 0.08 & $61.56^{\mathrm{a}}$ \\
\hline $4-1$ & b & 12.86 & $\mathrm{Fl}$ & 46.14 & 3.02 & 0.07 & 27.30 & 0.15 & 4.61 & 0.59 & 0.10 & 4.25 & 86.23 \\
\hline $4-1$ & b & & Fc & 0.98 & 0.92 & nd & 3.44 & 0.07 & 2.21 & 46.04 & 0.16 & 0.10 & $53.95^{\mathrm{a}}$ \\
\hline $4-5$ & & 17.77 & F] & 35.88 & 9.43 & 0.12 & 29.38 & 0.32 & 7.56 & 1.29 & 0.36 & 1.82 & 86.15 \\
\hline $4-5$ & & & $\mathrm{Fc}$ & 51.02 & 2.77 & nd & 25.45 & 0.07 & 3.93 & 0.50 & 0.04 & 6.46 & 90.27 \\
\hline $10-6$ & & 69.92 & F] & 39.20 & 7.04 & nd & 10.41 & 0.33 & 23.00 & 0.90 & 0.16 & 0.15 & 81.22 \\
\hline $10-6$ & & & $\mathrm{Fc}$ & 39.91 & 7.67 & nd & 12.71 & 0.11 & 22.12 & 0.75 & 0.15 & 0.17 & 83.62 \\
\hline
\end{tabular}

Note: $\mathbf{A l}=$ amygdule lining; Ail = amygdule inner layer; $\mathbf{A c}=$ amygdule center; $\mathbf{F l}=$ fracture lining; $\mathbf{F c}=$ fracture center; nd = not detected.

${ }^{a}$ Low total due to hydroxide or carbonate.

$$
\begin{aligned}
& \left(\mathrm{K}_{0.14} \mathrm{Ca}_{0.14} \mathrm{Na}_{0.04}\right)_{0.32}\left(\mathrm{Si}_{6.73} \mathrm{Fe}_{0.72} \mathrm{Al}_{0.55}\right)_{8} \\
& \left(\mathrm{Mg}_{4.12} \mathrm{Fe}_{2.85} \mathrm{Mn}_{0.01}\right)_{6.98} \mathrm{O}_{20}(\mathrm{OH})_{4} \cdot \mathrm{nH}_{2} \mathrm{O}
\end{aligned}
$$

Excess $\mathrm{Mg}$ and $\mathrm{Fe}$, here placed in the octahedral layer, might be from closely associated $\mathrm{Mg}-, \mathrm{Fe}$-hydroxides. This smectite appears to be an Fe-rich saponite that is slightly deficient in $\mathrm{Si}$ and $\mathrm{Al}$. As shown in Table 3, toward the center of the amygdule, the filling becomes depleted in $\mathrm{Mg}(6.58 \% \mathrm{MgO})$ and enriched in $\mathrm{Si}(53.07 \%$ $\left.\mathrm{SiO}_{2}\right)$ and $\mathrm{K}\left(5.82 \% \mathrm{~K}_{2} \mathrm{O}\right)$ to form an iron-rich hydromica. A structural formula for this mica, calculated on the basis of 22 oxygens, is of the form

$$
\left(\mathrm{K}_{1.17} \mathrm{Ca}_{0.09} \mathrm{Na}_{0.01}\right)_{1.27}\left(\mathrm{Si}_{8.00}\right)_{8}
$$

$\left(\mathrm{Fe}_{2.79} \mathrm{Mg}_{1.54} \mathrm{Si}_{0.37} \mathrm{Al}_{0.15} \mathrm{Mn}_{0.01}\right)_{4.86} \mathrm{O}_{20}(\mathrm{OH})_{4} \cdot \mathrm{nH}_{2} \mathrm{O}$,

which resembles a K-deficient celadonite composition (i.e., celadonitic clay). By comparison, an amygdule in Sample $597 \mathrm{C}-3-1 \mathrm{~b}$ is filled with green birefringent clay in the outer layers and a blue green mica in the center. Elemental analysis of the amygdule filling (Table 3 ) established the presence of two mineral phases including (1) an Ferich saponite, structural formula

$$
\begin{aligned}
& \left(\mathrm{Ca}_{0.12} \mathrm{~K}_{0.11} \mathrm{Na}_{0.03}\right)_{0.26}\left(\mathrm{Si}_{7.07} \mathrm{Fe}_{0.57} \mathrm{Al}_{0.36}\right)_{8} \\
& \left(\mathrm{Mg}_{4.32} \mathrm{Fe}_{2.41} \mathrm{Mn}_{0.01}\right)_{6.74} \mathrm{O}_{20}(\mathrm{OH})_{4} \cdot \mathrm{H}_{2} \mathrm{O}
\end{aligned}
$$

in the outer layer and (2) a celadonite phase $\left(\mathrm{K}_{2} \mathrm{O}>\right.$ $6 \%$ ), structural formula

$$
\begin{gathered}
\left(\mathrm{K}_{1.36} \mathrm{Ca}_{0.09} \mathrm{Ma}_{0.02}\right)_{1.47}\left(\mathrm{Si}_{8.00}\right)_{8} \\
\left(\mathrm{Fe}_{2.73} \mathrm{Mg}_{1.60} \mathrm{Si}_{0.26} \mathrm{Al}_{0.23}\right)_{4.82} \mathrm{O}_{20}(\mathrm{OH})_{4} \cdot \mathrm{nH}_{2} \mathrm{O}
\end{gathered}
$$

in the amygdule center. Both amygdules analyzed demonstrate an enrichment of $\mathrm{Si}$ and $\mathrm{K}$ and an increase in $\mathrm{FeO} / \mathrm{MgO}$ ratio with progressive infilling, confirming petrographic evidence that celadonite occurs as a late-stage alteration product in Site 597 basalt amygdules.

Amygdules filled with opaque minerals were analyzed by microprobe and are found to comprise both $\mathrm{Fe}$ - and Mn-hydroxides, with $\mathrm{FeO}: \mathrm{MnO}$ ratios generally decreasing toward amygdule centers. For example, an opaque amygdule filling in Sample 597C-3-1b (Table 3) shows an extreme transition in composition from the amygdule $\operatorname{rim}(61.58 \% \mathrm{FeO}, 0.16 \% \mathrm{MnO})$ to the amygdule center $(1.39 \% \mathrm{FeO}, 66.3 \% \mathrm{MnO})$. Such a transition is likely to occur under increasingly oxidative conditions, because the formation of lower-redox-potential iron phases precedes the formation of higher-redox-potential Mn phases (Froelich et al., 1979).

Elemental analyses of clay- and carbonate-filled amygdules in Sample 597C-3-2 (Table 3) establish that the formation of Fe-rich saponite in amygdule linings was followed by the formation of low-Mg carbonate, probably calcite, in amygdule centers.

Microprobe analyses of sequentially formed minerals in fracture fillings give results generally similar to those obtained for amygdule fillings. For example, a fracture lining in Sample 597C-4-1b, from a basement depth of $12.86 \mathrm{~m}$, contains a green birefringent nontronite $(27.30 \%$ $\mathrm{FeO}, 4.61 \% \mathrm{MgO}$ ) adjacent to a calcite-filled fracture center (Table 3). Another fracture lining in Sample 597C4-5, from a basement depth of $17.77 \mathrm{~m}$, is made up of a green birefringent nontronite $(29.38 \% \mathrm{FeO}, 7.56 \% \mathrm{MgO})$, and the fracture center contains a blue green celadonite $\left(6.46 \% \mathrm{~K}_{2} \mathrm{O}\right)$.

The nontronite in Sample 597C-4-5 appears to be closely associated with or to be replacing chlorite and might account for the low-Si composition $\left(35.88 \% \mathrm{SiO}_{2}\right)$ of 
this smectite fracture lining. It is interesting that the microprobe analyses indicate the presence of saponites in the amygdule rims; the fracture linings contain only nontronite. The amygdules might record an early deuteric alteration stage (Bass, 1976) that occurred prior to the onset of extensive hydrothermal circulation in opening rock fractures. Finally, microprobe analyses of a fracture filling in Sample 597C-10-6 (basement depth 74.35 m) establish that both lining and center are made up of $\mathrm{Mg}$ rich phyllosilicates. These compositional analyses verify $\mathrm{X}$-ray diffraction analyses of the fracture filling that indicate the presence of trioctahedral chlorite and talc.

The results of the microprobe, X-ray diffraction, and petrographic analyses of the Site 597 alteration products can be combined to provide a relatively complete sequence of hydrothermal secondary mineral formation and subsequent oxidative alteration in the upper $70 \mathrm{~m}$ of Site 597 basement. Initial crystallization of secondary minerals generally occurred in the following order: (1) trioctahedral chlorite and talc, (2) $\mathrm{Mg}$-, Fe-smectite, (3) goethite and Mn-hydroxides, and (4) celadonitic clay, celadonite, and calcite. Late-stage overprinting of these minerals by oxidative fluids resulted in localized $\mathrm{Fe}-\mathrm{ox}$ ide staining. Finally, extensive alteration by low-temperature oxidative solutions resulted in the pervasive replacement of unstable primary grains and groundmass by calcite and minor amounts of phillipsite in the upper $17 \mathrm{~m}$ of Site 597 basement.

\section{K-Ar DATING OF CELADONITE IN FRACTURE FILLINGS IN SITE 597 BASALTS}

Three celadonite-rich mineral separates were isolated from fracture fillings in Samples 597B-3-1b, 597C-4-5, and $597 \mathrm{C}-9-3 \mathrm{~b}$ for $\mathrm{K}-\mathrm{Ar}$ age determination of secondary mineralization in Site 597 basalts. Atomic absorption analyses of the three mineral separates gave potassium concentrations of $3.7 \%, 2.7 \%$, and $4.4 \%$ for Samples 597B-3-1b, 597C-4-5, and 597C-9-3b, respectively, confirming the presence of potassium-rich phases. Diffractograms of mineral separates from these three samples (Fig. 1) indicate the presence of celadonitic clay in two samples (597B-3-1b and 597C-4-5) and well crystallized celadonite in the third sample (597C-9-3b).

As noted above, celadonite is a dioctahedral phyllosilicate commonly formed in association with calcite in oxidative, low-temperature conditions of basalt alteration (Bass, 1976). Although celadonite and glauconite are distinct minerals (Buckley et al., 1978), the average composition and structural formulae of celadonite and glauconite, a mineral that forms diagenetically in shallow-water marine sediments, are very similar. Glauconite has been used successfully to date the deposition of sedimentary rocks (Curtis and Reynolds, 1958; Lipson, 1958; Hurley et al., 1961; Hurley, 1966). The main compositional differences between the two minerals appear to reside in the octahedral sheet, where celadonite contains more $\mathrm{Mg}$ and less $\mathrm{Fe}^{3+}$ than glauconite, and in the tetrahedral sheet, where glauconite has a higher $\mathrm{Al}$ content than celadonite.

Because of its extremely small grain size, glauconite loses argon more easily than other micas (e.g., biotite, muscovite), and measured ages reveal argon loss even during burial to only a few thousand feet, where temperatures might reach 150 to $200^{\circ} \mathrm{C}$ for a prolonged period (Dalrymple and Lanphere, 1969; Aronson and Hower, 1976). Celadonite, however, forms at low temperatures in basalts on the ocean floor $\left(0\right.$ to $30^{\circ} \mathrm{C}$; Seyfried et al., 1978) and would not be exposed to elevated temperatures following crystallization, so total retention of radiogenic argon would be expected. The brief low-temperature bakeout prior to argon extraction should not cause the diffusion of significant quantities of argon from the celadonite samples. Hence, celadonite should provide reliable ages for low-temperature vein-filling alteration. Its high $\mathrm{K}_{2} \mathrm{O}$ content (Tables 3 and 4) makes it particularly attractive for the $\mathrm{K}-\mathrm{Ar}$ radiometric analysis of rock in which vein minerals are small and often intergrown, because in rock of this kind the separation of large amounts of pure phases is difficult.

In Table 4 we present the first reported $\mathrm{K}-\mathrm{Ar}$ analyses of celadonite formation ages. Samples 597C-4-5, a celadonitic clay from $17.77 \mathrm{~m}$ (Hole 597C), and 597C-9-3b, a well crystallized celadonite from $60.35 \mathrm{~m}$ (Hole 597C), yield ages of $19.9 \pm 0.4$ m.y. and $19.3 \pm 1.6$ m.y., respectively; these ages are identical within the analytical uncertainty $(1 \sigma)$. The equivalence of these ages indicates that reliable ages can be obtained from celadonitic clay and that late-stage celadonite formation occurred during roughly the same time period at two widely separated basement depths (i.e., $18 \mathrm{~m}$ and $60 \mathrm{~m}$ ) at Hole 597C. By comparison, Sample 597B-3-16, a celadonitic clay from $16.75 \mathrm{~m}$ basement depth in Hole 597B, is significantly younger at $13.1 \pm 0.3 \mathrm{~m} . \mathrm{y}$. and indicates that celadonite formation continued at least intermittently for another $6 \mathrm{~m}$.y. The more open fracture system observed at shallow basement depths ( $\leq 17 \mathrm{~m})$ in both Holes 597B and 597C apparently allowed secondary mineralization to occur much longer than in deeper, more constricted fracture systems.

The possibility that the younger age from Hole 597B is due to diffusive argon loss is, we feel, unlikely. All three samples are structurally similar, so argon diffusion should not occur more rapidly in the sample of intermediate potassium content. The samples have not been heated above the ambient ocean floor temperature since celadonite formation. Finally, the dating of celadonites from other deep sea drilling sites (Hole 417D) and ophiolites (Troodos complex, Cyprus) yields concordant ages that are in agreement with $\mathrm{Rb}-\mathrm{Sr}$ isochron ages on the same alteration minerals (Duncan et al., 1984; Staudigel et al., 1986).

The age of basalt crystallization at Site 597 is determined from biostratigraphic and magnetic anomaly evi-

Table 4. $\mathrm{K}-\mathrm{Ar}$ determinations for celadonite and proto-celadonite from Site 597 altered basalts.

\begin{tabular}{lccccc}
\hline Sample & Mineral & $\begin{array}{c}\mathrm{K} \\
(\%)\end{array}$ & $\begin{array}{c}\text { Radiogenic }{ }^{40} \mathrm{Ar} \\
\left(\mathrm{cm}^{3} / \mathrm{g} \times 10^{-5}\right)\end{array}$ & $\begin{array}{c}\text { Radiogenic } \\
(\%)\end{array}$ & $\begin{array}{c}\text { Age } \pm 10 \\
\left(\mathrm{yr} . \times 10^{6}\right) \mathrm{a}\end{array}$ \\
\hline 597B-3-1b & Celadonitic clay & 3.71 & 0.18912 & 39.5 & $13.1 \pm 0.3$ \\
597C-4-5 & Celadonitic clay & 2.71 & 0.21031 & 54.5 & $19.9 \pm 0.4$ \\
597C-9-3b & Celadonite & 4.41 & 0.26581 & 11.1 & $19.3 \pm 1.6$ \\
\hline
\end{tabular}

a Ages were calculated from the following decay and abundance constants: $\lambda_{\epsilon}=0.581 \times$ $10^{-10} / \mathrm{yr}$; $\lambda_{\beta}=4.962 \times 10^{-10} / \mathrm{yr}$.; $40 \mathrm{~K} / \mathrm{K}=1.167 \times 10^{-4} \mathrm{~mol} / \mathrm{mol}$. 
dence to be 28.6 m.y. (Rea, this volume). Comparing this age with the celadonite ages suggests that hydrothermal circulation and corresponding secondary mineralization continued for 10 to $16 \mathrm{~m}$.y. after ocean crust formed at the ridge crest. Clearly, more radiometric ages from a single hole are needed to provide detail about the timing of celadonite mineralization with depth.

\section{DISCUSSION}

Secondary minerals precipitated in fracture and pore spaces provide the most direct available record of hydrothermal circulation and of the conditions associated with the hydrothermal alteration of the massive seafloor basalts recovered from Site 597. Mineral separates from fracture fillings in the Site 597 basalts are largely composed of chlorite, goethite, and calcite, with minor amounts of talc, $\mathrm{Fe}$ - and $\mathrm{Mg}$-smectite, and celadonite. This secondary mineral assemblage is similar to alteration product assemblages reported for other east Pacific seafloor basalts formed along fast-spreading ridges (Stakes and Scheidegger, 1981). However, the Site $597 \mathrm{sec}-$ ondary mineral assemblage contrasts with the high-temperature chlorite-albite-quartz-epidote greenstone assemblages (Stakes and O'Neil, 1982) and the low-temperature smectite-carbonate assemblages (Humphris et al., 1980) in basalts formed along the slower spreading Mid-Atlantic Ridge. The abundance of $\mathrm{Mg}$-rich phases, including trioctahedral chlorite and talc, from basement depths of $>60 \mathrm{~m}$ denotes possible enrichment by seawater $\mathrm{Mg}$ and implies high water:rock ratios during alteration (Mottl and Seyfried, 1980). Additional evidence of high water:rock alteration conditions is provided by the abundance of both Fe-rich phases, including dioctahedral phyllosilicates, above basement depths of $20 \mathrm{~m}$, and goethite, which is found throughout the section. Iron-rich phases are formed under conditions of high water:rock ratios or high alteration temperatures $\left(>300^{\circ} \mathrm{C}\right)$, and the presence of $\mathrm{Fe}$-saponites formed at lower temperatures $\left(<170^{\circ} \mathrm{C}\right)$ (Stakes and O'Neil, 1982) points to high water:rock ratio conditions rather than high alteration temperatures.

The alteration history of the upper $70 \mathrm{~m}$ of Site 597 basalt is well preserved in sequentially formed secondary mineral assemblages that vary in downcore distribution. For example, an initial period of high-temperature $\left(>200^{\circ} \mathrm{C}\right.$ ) nonoxidative alteration by $\mathrm{Mg}$-bearing hydrothermal fluids is indicated by trioctahedral chlorite and talc assemblages from depths of $>60 \mathrm{~m}$ in basement (Fig. 4). This early period of alteration was followed by alteration conditions of lower temperature $\left(<170^{\circ} \mathrm{C}\right)$ and higher oxidation which, in association with fluids possibly enriched in Fe from the breakdown of primary mafic minerals (Scheidegger and Stakes, 1977), formed goethite and dioctahedral smectite. Finally, a late-stage alteration assemblage includes celadonitic clay, celadonite, and calcite-filled amygdule and fracture centers in basalts above depths of $45 \mathrm{~m}$ in basement, and celadonite without calcite at greater basement depths (i.e., at least $66 \mathrm{~m})$. This late-stage assemblage signifies (1) increasingly more oxidative conditions, (2) low temperature of formation $\left(<30^{\circ} \mathrm{C}\right.$; Seyfried et al., 1978), and (3) fluid enrichment in $\mathrm{Ca}$ ( $<45 \mathrm{~m}$ in basement depth), possibly either from the breakdown of primary feldspars (Scheidegger and Stakes, 1977) or from seawater leaching of overlying, carbonate-rich sediments (Lyle, this volume).

An additional alteration event that might have continued long after late-stage hydrothermal alteration had ceased at Site 597 is the pervasive, oxidative alteration of unstable grains and groundmass in the upper $\approx 17 \mathrm{~m}$ of basement. Calcite is the predominant alteration product in this pervasive alteration zone; however, late phillipsite also occurs in minor amounts and suggests a very low temperature of formation, probably close to ambient seawater $\left(\approx 0^{\circ} \mathrm{C}\right.$; Böhlke et al., 1980).

$\begin{array}{ll}\begin{array}{l}\text { Alteration } \\ \text { conditions: }\end{array} & \begin{array}{l}\mathrm{T}>200^{\circ} \mathrm{C}, \\ \text { nonoxidative }\end{array} \\ \begin{array}{l}\text { Mineral } \\ \text { assemblages: }\end{array} & \mathrm{Mg} \text { chlorite } \\ & \mathrm{Mg} \text { talc } \\ \text { Overprinting: } & \text { None }\end{array}$

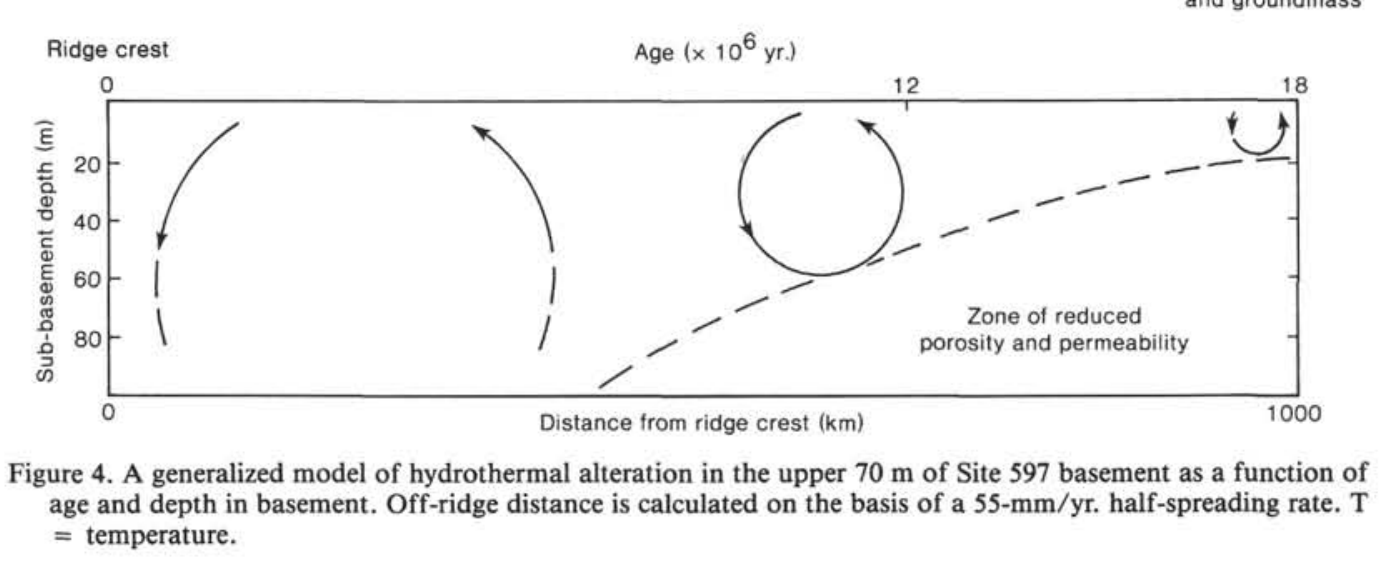

Figure 4. A generalized model of hydrothermal alteration in the upper $70 \mathrm{~m}$ of Site 597 basement as a function of age and depth in basement. Off-ridge distance is calculated on the basis of a 55-mm/yr. half-spreading rate. T $=$ temperature.

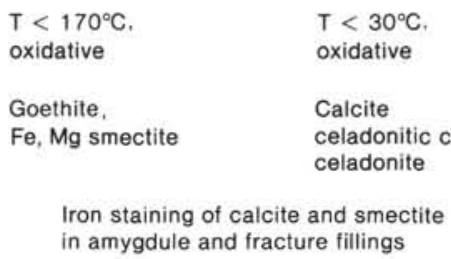

$T \sim 0^{\circ} \mathrm{C}$

Calcite, phillipsite

Pervasive alteration of unstable grains and groundmass 
Oxidative alteration by both cold seawater processes and hydrothermal circulation decreases dramatically with increasing depth in the upper $70 \mathrm{~m}$ of Site 597 basement. The relatively shallow zone of intense alteration contrasts with the much deeper zone of low-temperature alteration at DSDP Sites 332B and 418A (Scarfe, 1980); the contrast reflects the low porosity and permeability of the Site 597 massive seafloor basalts. In addition, a zone of oxidative alteration became shallower with time as the precipitation of secondary minerals filled available fracture spaces. A process of this kind accounts for the decrease in the proportion of oxidative mineral assemblages with increasing depth in Hole 597C and is consistent with the sequential precipitation of successively more oxidative mineral assemblages established for amygdule and fracture fillings at shallow basement depths.

The timing of hydrothermal alteration in the upper $60 \mathrm{~m}$ of Site 597 basalts is constrained by the age of basalt formation ( $28.6 \mathrm{~m}$.y.) and the $\mathrm{K}-\mathrm{Ar}$ dating of celadonite formation (13 m.y. and 19 m.y.). The presence of trioctahedral chlorite and talc, which form under nonoxidative conditions at moderately high temperatures $\left(>200^{\circ} \mathrm{C}\right.$ ), suggests that hydrothermal alteration by $\mathrm{Mg}-$ bearing seawater probably occurred soon after basalt formation at the Mendoza Rise. In contrast, celadonite and calcite precipitation are associated with amygdule and fracture-filling centers, a mode of occurrence that indicates that this assemblage marks the final stage of hydrothermal circulation and alteration in Site 597 basalts. Differences in celadonite formation ages (13 m.y. at 17 $\mathrm{m}$ in Hole 597B and $19 \mathrm{~m} . \mathrm{y}$. at $18 \mathrm{~m}$ in Hole 597C) reflect an extended period of secondary mineralization (at least 6 m.y.) at shallow basement depths. This extended period of alteration might be associated with the pervasive oxidative alteration of upper basement rocks $(<20$ $\mathrm{m}$ depth).

Hydrothermal alteration occurred for some 10 to 16 m.y. after host rock formation on the Mendoza Rise. If we assume a half-spreading rate of $55 \mathrm{~km} / \mathrm{m}$.y. (Rea, this volume), hydrothermal circulation was active in the uppermost basaltic crust at a distance of at least $550 \mathrm{~km}$ off ridge crest and possibly at a distance of nearly 1000 $\mathrm{km}$ off ridge crest (Fig. 4).

\section{ACKNOWLEDGMENTS}

We thank Mark Hower for help with laboratory analyses and Carolyn Peterson for assistance with figure drafting. Miriam Kastner and Richard Shepard provided help with mineral identification. The review of the manuscript provided thoughtful suggestions for its improvement.

\section{REFERENCES}

Aronson, J. L., and Hower, J., 1976. Mechanisms of burial metamorphism of argillaceous sediment. 2. Radiogenic argon evidence. Bull. Geol. Soc. Am., 87:738-744.

Bass, M. N., 1976. Secondary minerals in oceanic basalts, with special reference to Leg 34, Deep Sea Drilling Project. In Yeats, R. S., Hart, S. R., et al., Init. Repts. DSDP, 34: Washington (U.S. Govt. Printing Office), 393-432.

Böhlke, J. K., Honnorez, J., and Honnorez-Guerstein, B. M., 1980. Alteration of basalts from Site 396B, DSDP: petrographic and mineralogic studies. Mineral. Petrol., 73:341-364.

Buckley, H. A., Bevan, J. C., Brown, K. M., Johnson, L. R., and Farmer, V. C., 1978. Glauconite and celadonite: two separate mineral species. Mineral. Petrol., 42:373-382.
Curtis, G. H., and Reynolds, J. H., 1958. Notes on potassium-argon dating of sedimentary rocks. Bull. Geol. Soc. Am., 69:151-159.

Dalrymple, G. B., and Lanphere, M. A., 1979. Potassium-Argon Dating: San Francisco (W. H. Freeman).

Duncan, R. A., Peterson, C., and Scheidegger, K. F., 1984. The duration of hydrothermal circulation in crust from age determinations on celadonite. Trans. Am. Geophys. Union, 65:1126.

Froelich, P. N., Klinkhammer, G. P., Bender, M. C., Luedtke, N. A., Heath, G. R., Cullen, D., and Dauphin, P., 1979. Early oxidation of organic matter in pelagic sediments of the eastern equatorial Atlantic suboxic diagenesis. Geochim. Cosmochim. Acta, 43:10751090.

Hart, R. A., 1970. Chemical exchange between sea water and deep ocean basalts. Earth Planet. Sci. Lett., 9:269.

Honnorez, J., 1983. Basalt-seawater exchange: a perspective from an experimental viewpoint. In Rona, P. A., Boström, K., Laubier, L. and Smith, E. L (Eds.), Hydrothermal Processes at Seafloor Spreading Centers: New York (Plenum Press), pp. 168-176.

Humphris, S. E., Thompson, R. N., and Marriner, G. F., 1980. The mineralogy and geochemistry of basalt weathering, Holes $417 \mathrm{~A}$ and 418A. In Donnelly, T., Francheteau, J., Bryan, W., Robinson, P., Flower, M., Salisbury, M., et al., Init. Repts. DSDP, 51, 52, 53, Pt. 2: Washington (U.S. Govt. Printing Office), 1201-1217.

Hurley, P. M., 1966. K-Ar dating of sediments. In Schaeffer, O. A., and Zahringer, J. (Eds), Potassium-Argon Dating: New York (Springer-Verlag), pp. 134-151.

Hurley, P. M., Brookins, D. G., Pinson, W. H., Hart, S. R., and Fairbairn, H. W., 1961. K-Ar age studies of Mississippi and other river sediments. Bull. Geol. Soc. Am., 72:1807-1816.

Lipson, J., 1958. Potassium-argon dating of sedimentary rocks. Bull. Geol. Soc. Am., 69:137-149.

Mottl, M. J., and Seyfried, W. E., 1980. Sub-seafloor hydrothermal systems: rock- vs. seawater-dominated. In Rona, P. A., and Cowell, R. P. (Eds.), Seafloor Spreading Centers: Hydrothermal Systems: Stroudsburg, PA (Dowden, Hutchinson, and Ross), pp. 6682.

Rosenbauer, K. J., Bischoff, J. L., 1983. Uptake and transport of heavy metals by heated seawater: a summary of the experimental results. In Rona, P. A., Boström, K., Laubier, L., and Smith, E. L. (Eds.), Hydrothermal Processes at Seafloor Spreading Centers: New York (Plenum Press), pp. 177-198.

Scarfe, C. M., 1980. Secondary minerals in some basaltic rocks from Deep Sea Drilling Project Legs 52 and 53, Hole 418A. In Donnelly, T., Francheteau, J., Bryan, W., Robinson, P., Flower, M., Salisbury, M., et al., Init. Repts. DSDP, 51, 52, 53, Pt. 2: Washington (U.S. Govt. Printing Office), 1243-1252.

Scheidegger, K. F., and Stakes, D. S., 1977. Mineralogy, chemistry and crystallization sequence of clay minerals in altered tholeitic basalts from the Peru trench. Earth Planet. Sci. Lett., 36:413-422. , 1980. X-ray diffraction and chemical study of secondary minerals from Deep Sea Drilling Project Leg 51, Holes 417A and 417D. In Donnelly, T., Francheteau, J., Bryan, W., Robinson, P., Flower, M., Salisbury, M., et al., Init. Repts. DSDP, 51, 52, 53, Pt. 2: Washington (U.S. Govt. Printing Office), 1253-1263.

Seyfried, W. E., Shanks, W. C., III, and Dibble, W. E., Jr., 1978. Clay mineral formation in DSDP Leg 34 basalt. Earth Planet. Sci. Lett., 41:265-276.

Stakes, D. S., and O'Neil, J. R., 1982. Mineralogy and stable isotope geochemistry of hydrothermally altered oceanic rocks. Earth Planet. Sci. Lett., 57:285-304.

Stakes, D. S., and Scheidegger, K. F., 1981. Temporal variations in secondary minerals from Nazca Plate basalts, diabases and microgabbros. In Kulm, L. D., Dymond, J., Dasch, E. J., and Hussong, D. M. (Eds.), Nazca Plate: Crustal Formation and Andean Convergence. Geol. Soc. Am. Mem., 154:109-130.

Staudigel, H., Gillis, K., and Duncan, R., 1986. K/Ar and $\mathrm{Rb} / \mathrm{Sr}$ ages of celadonites from the Troodos ophiolite, Cyprus. Geology, 14:72-75.

Thompson, G., 1983. Basalt-seawater interaction. In Rona, P. A., Boström, K., Laubier, L., and Smith, E. L. (Eds.), Hydrothermal Processes at Seafloor Spreading Centers: New York (Plenum Press), pp. 225-278.

Date of Initial Receipt: 13 August 1984

Date of Acceptance: 4 January 1985 


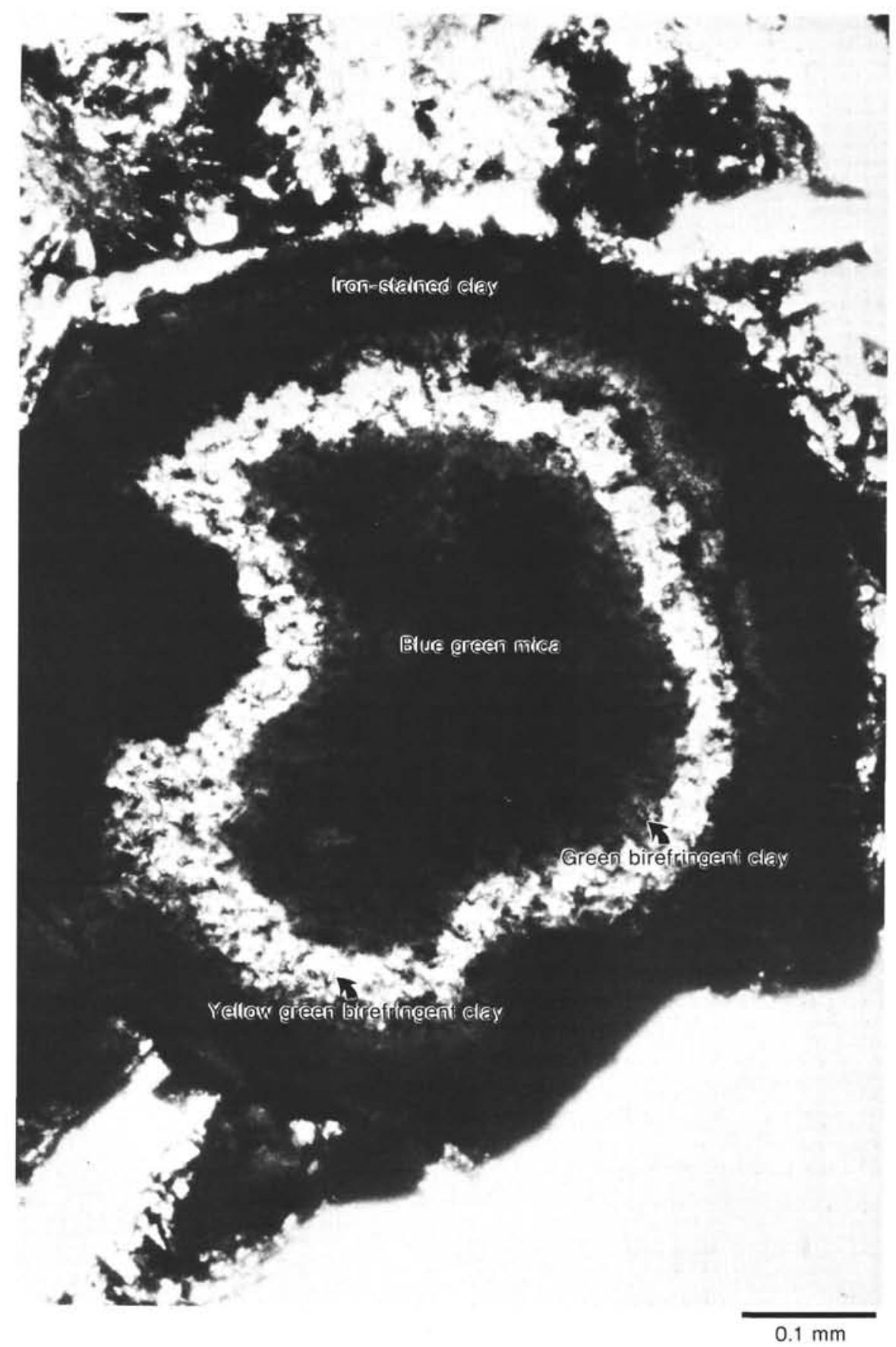

Plate 1. A clay- and mica-filled amygdule from Sample 597C-3-1a showing sequential formation of (1) yellow-green birefringent clay, (2) darker green, birefringent clay, (3) blue green mica, and (4) late-stage iron staining of amygdule rim. 


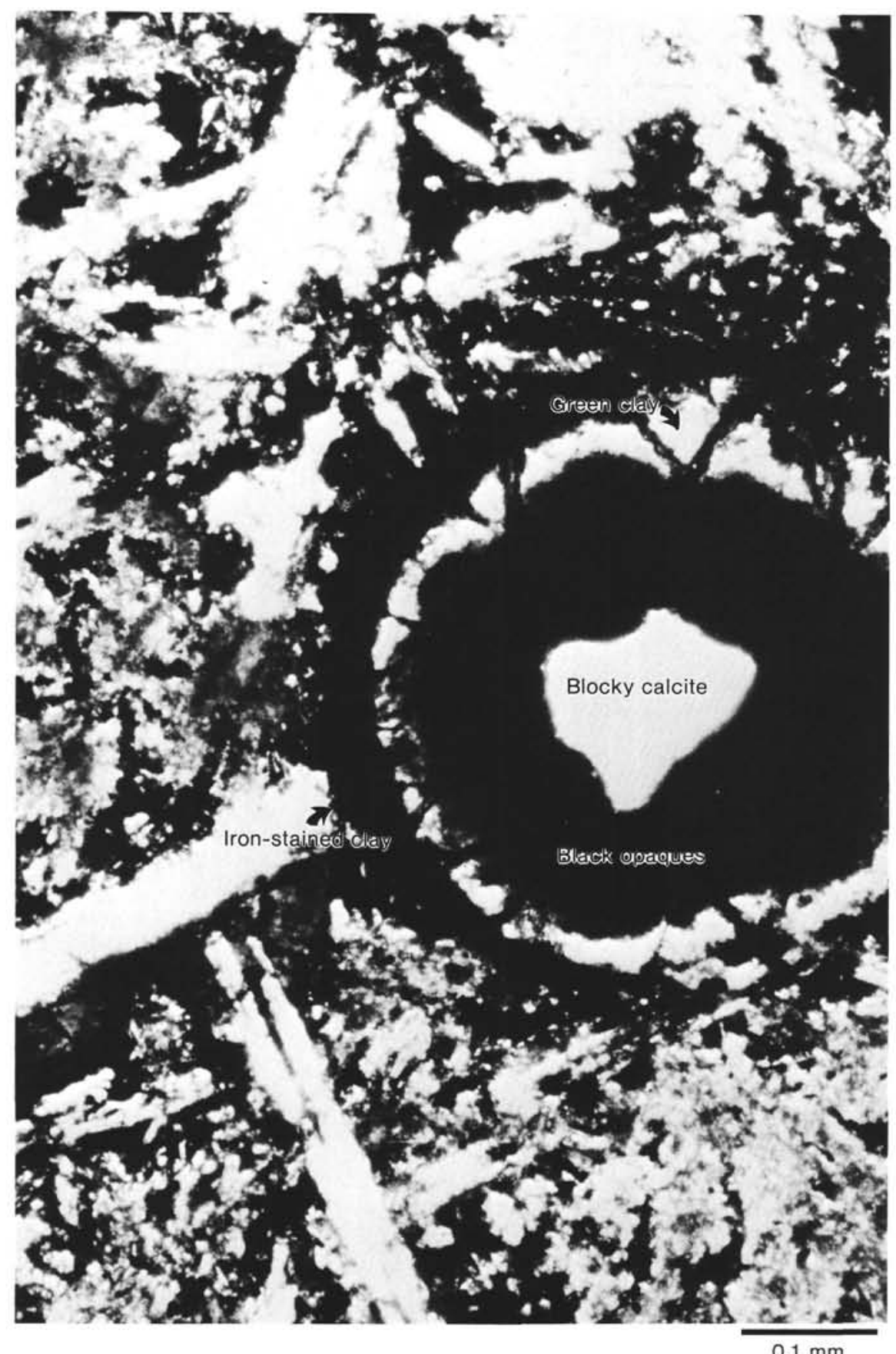

Plate 2. A clay-, opaque mineral-, and carbonate-filled amygdule from Sample 597C-3-1b demonstrating sequential infilling by (1) light green, birefringent clay, (2) black opaque minerals, and (3) blocky calcite. Late-stage iron staining of the amygdule rim blends into groundmass that is pervasively altered and replaced by carbonate and minor zeolite. 